Virus Laboratory, Department of Epidemiology, School of Public Health, The University of Michigan, Ann Arbor, Michigan, U.S.A.

\title{
Nucleo-cytoplasmic Studies in the Development of Influenza Virus in Mammalian Cells
}

\author{
By
}

\author{
W. C. Bell ${ }^{1}$ and H. F. Maassa ${ }^{2}$ \\ With 4 Figures \\ (Received September 5, 1968)
}

Investigations concerning the intracellular development of influenza virus have centered primarily on the fowl plague virus - primary chick embryo cell system. These studies have utilized both fluorescent antibody techniques and biochemical analyses to follow the time course of viral synthesis (BReitenfeld and Schäfte, 1967; Scholttssek and Rott, $1961 \mathrm{a}, \mathrm{b}$; Scholtissex et al., 1962). Later studies concerning the mode of viral ribonucleic acid replication have used influenza virus adapted to the chick embryo fibroblast cell system (Pons, 1967a, b; DuesBERG and Robinson, 1967; NAYAK and BaLUda, 1968a, b).

The use of a continuous mammalian cell line for studies of this nature offers advantages not found with primary and secondary cell cultures such as homogeneity of cell type, uniform susceptibility to infection and usually a lack of adventitious agents. Several continuous mammalian cell lines have been shown to support the complete growth of influenza viruses. One such line, clone 1-5c-4 of Chang's conjunctival cell (Wong and Kilbourne, 1961; SUgIURA and Kilbourne, 1965) was used throughout these studies.

1 This paper is part of a dissertation submitted by William C. BeLl in partial fulfillment of the requirements for the degree of Doctor of Philosophy from the University of Michigan. Supported in part by Graduate Training Grants from Nat. Inst. of Allergy and Infect. Dis., NIH 5 T1 AI-60.

2 This investigation was conducted in part under the sponsorship of the Commission on Influenza, Armed Forces Epidemiological Board, and was supported by the U.S. Army Medical Research and Development Command, Department of the Army, under research contract DA-49-193-MD-2066. 
By means of a non-ionic detergent method of cell fractionation we have attempted to follow the development of influenza A-NWS-induced nucleic acid synthesis in the nucleus and cytoplasm of 1-5c-4 cells. The two cell fractions obtained at various intervals during the infectious cycle were analyzed for the amount of acid precipitable, radioactively labelled nucleic acid, present in both infected and control cell cultures.

\section{Materials}

Cells. Clone 1-5c-4 of Chang's conjunctival cell, kindly provided by Dr. F. I. KILBourNe, was propagated and grown according to the method of Sugrura and Kilbourne (1965). The cells were seeded at a density of $5 \times 10^{5}$ cells per $\mathrm{ml}$ of culture fluid. For biochemical analysis $10 \mathrm{ml}$ of cell suspension were added per 8 ounce flint glass prescription bottle. Plastic Petri dishes, $60 \times 15 \mathrm{~mm}$ (Falcon Plastics) were seeded with $5 \mathrm{ml}$ of cell suspension. The cells were incubated at $36^{\circ} \mathrm{C}$ in a humidified atmosphere of $5 \% \mathrm{CO}_{2}$. Complete monolayers were formed in 4 to 6 days after seeding.

Virus. Influenza A-NWS (STUART-HARRIs, 1939) adapted to 1-5c-4 cells was obtained from Dr. E. D. KILBouRne. The virus was grown allantoically in 10 to 11 day old embryonated eggs, harvested after 48 hours, and stored at $-80^{\circ} \mathrm{C}$ until use.

Chemicals. ${ }^{3} \mathrm{H}$-Uridine; $20 \mathrm{c} / \mathrm{m}$ mole and ${ }^{3} \mathrm{H}$-Thymidine; $13 \mathrm{c} / \mathrm{m}$ mole were purchased from Schwartz Bio Research, Inc., Orangeburg, New York. Actinomycin D was a gift of MERcK SHARP and Dohme Research Laboratories.

Diluent and maintenance medium. Eagle's basal medium containing twice the contribution of amino acids and vitamins with $0.1 \%$ bovine serum albumin fraction $V$ was used as a diluent for virus and maintenance medium. In the biochemical studies actinomycin D was added at a concentration of $0.01 \mu \mathrm{g} / \mathrm{ml}$.

Plaque assay. 1-5c-4 cells were used as soon as possible after the formation of a confluent cell sheet. Growth medium was removed by aspiration, and the monolayer, washed twice with Hanks' BSS (HANks and WALLACE, 1949) containing $0.1 \%$ bovine serum albumin fraction $\mathrm{V}$, was inoculated with $0.5 \mathrm{ml}$ of the appropriate virus dilution in maintenance medium. The virus was allowed to adsorb for one hour at $37^{\circ} \mathrm{C}$ with intermittent agitation in a humidified atmosphere of $5 \% \mathrm{CO}_{2}$. After adsorption the cultures were overlayed and stained using the method of Sugiura and Kilbourne (1965).

Titration of virus in eggs. Titrations of virus infectivity were made using either $\log _{10}$ or $0.5 \log _{10}$ dilutions of virus in broth. Embryonated 10 to 11 day old eggs were inoculated allantoically with $0.2 \mathrm{ml}$ of virus dilution using 4 eggs per dilution.

Hemagglutination titration. Serial two-fold dilutions of $0.25 \mathrm{ml}$ of virus in $0.25 \mathrm{ml}$ of phosphate buffered saline were prepared in a "Perspex" hemagglutination plate (FAzekas de ST Groth and Graham, 1954, 1955). The end points were read 60 minutes after the addition of $0.5 \mathrm{ml}$ of $0.5 \%$ chicken ergthrocytes.

Growth curve studies. Monolayers of $1-5 \mathrm{c}-4$ cells $\left(2\right.$ to $2.5 \times 10^{6}$ cells) were infected at a multiplicity of 10 plaque forming units per coll. The virus was adsorbed for 60 minutes with intermittent agitation at $37^{\circ} \mathrm{C}$ in a humidified atmosphere of $5 \% \mathrm{CO}_{2}$. After adsorption the cell sheet was washed twice with 
warm maintenance medium and overlayed with $5 \mathrm{ml}$ of maintenance medium and incubated under the conditions cited above.

Samples were taken at appropriate intervals and stored frozen at $-80^{\circ} \mathrm{C}$. Each sample was then thawed and cleared of cellular debris by low speed centrifugation prior to assaying for hemagglutinating activity and infectivity.

Cell fractionation. 1-5c-4 cells were fractionated using a modification of the non-ionic detergent procedure developed by Fisher et al. (1966). Hanks' BSS was substituted for Puck's saline " $\mathrm{F}$ " with no apparent difference in the efficiency of fractionation.

Biochemical studies. Cell monolayers grown in 8 ounce prescription bottles (approximately $8 \times 10^{6}$ cells), were infected with 10 plaque forming units of virus per cell in $1 \mathrm{ml}$ of maintenance medium. At appropriate intervals $5.0 \mu \mathrm{c}$ per culture of ${ }^{3} \mathrm{H}$-Uridine or ${ }^{3} \mathrm{H}$-Thymidine were added to both infected and control cultures for RNA and DNA studies, respectively. Culturcs were then incubated for 1 hour prior to removal for analysis. At the designated intervals the labelled cultures were washed twice with Hanks' BSS and fractionated. The nuclear and cytoplasmic fractions were frozen at $-80^{\circ} \mathrm{C}$ until analysis.

Analytical procedures. The nucleic acids were extracted from the cell fractions by a modification of the Schmidt-Thannhauser technique (MunRo and FLECK, 1966). The extracted RNA was determined colorimetrically by the orcinol procedure of Dische (1955). The content of DNA in the extracts was determined by the BuRTON (1956) modification of the Dische diphenylamine reaction (DISCHE, 1955).

Determination of radioactivity. $1 \mathrm{ml}$ of sample was added to $9 \mathrm{ml}$ of dioxanebased scintillation fluid (BUTLER, 1961) and counted in an Ansitron liquid scintillation counter (ANS, Inc.). The results of the biochemical determinations were then expressed as specific activity, counts per minute per microgram of nucleic acid.

\section{Results}

\section{Fractionation of $1-5 c-4$ Cells}

The fractionation of $1-5 \mathrm{c}-4$ cells and isolation of nuclei by stirring in the presence of low concentrations of Tween 80 gave results comparable to those described previously (FISHER and HARRIS, 1962a, b; and Fisher et al., 1966). Fig. 1 shows the appearance of whole cells before fractionation and the condition of the isolated nuclei after fractionation. The efficiency of the procedure was determined microscopically and the percentage of nuclei free of contaminating cytoplasmic material ranged from 93 to $96 \%$, with a spin time of $4-5$ minutes. The recovery of intact nuclei based on whole cell counts prior to fractionation was usually 92 to $94 \%$.

The contamination of the nuclear pellet with cytoplasmic contents was also determined to be negligible using the presence of glucose-6phosphate dehydrogenase as a criterion. The presence of whole cells, nuclei and nuclear debris in the cytoplasmic fractions was determined by following the distribution of ${ }^{3} \mathrm{H}$-thymidine labelled acid insoluble material between the nuclear pellet and the cytoplasmic extract. The specific activity (counts per minute per microgram of DNA) of labelled 
acid insoluble material found in the cytoplasmic fractions varied from 3 to $6 \%$ of that found in the nuclear pellet.

\section{Single Step Growth Curve}

A single cycle of influenza A-NWS growth was produced by infecting $1-5 \mathrm{c}-4$ cell monolayers with $10-20$ plaque forming units of virus per cell. The virus was allowed to adsorb, with intermittent agitation, at $37^{\circ} \mathrm{C}$ for 1 hour. The inoculum was then removed by aspiration and
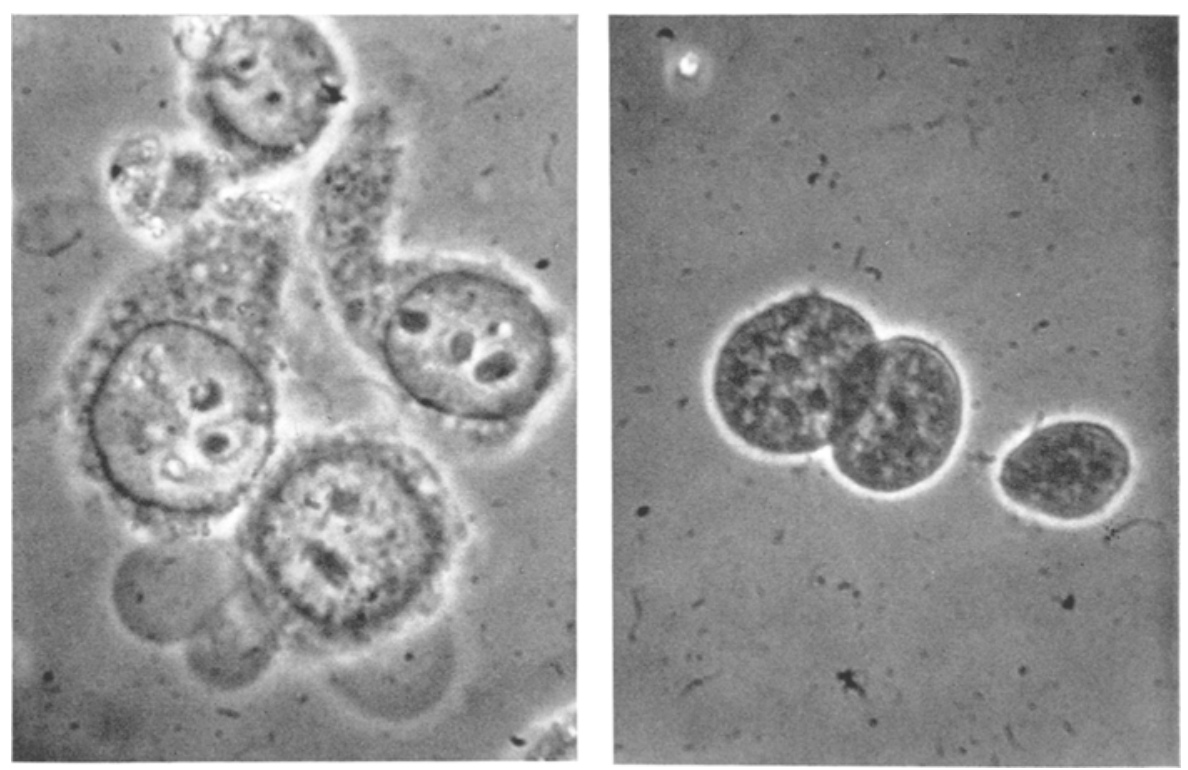

Fig. 1. Microscopic appearance of cells before nuclear isolation and nuclei after isolation procedure.

a) 1-5c-4 cells prior to fractionation with Tween $80 . \times 1200$.

b) Appearance of nuclei after fractionation with Tween $80 . \times 1200$.

the cell sheet washed twice with maintenance medium (without actinomycin D), overlayed with $5 \mathrm{ml}$ of liquid maintenance medium and incubated at $37^{\circ} \mathrm{C}$ in a humidified atmosphere at $5 \% \mathrm{CO}_{2}$. Samples were removed at appropriate intervals and frozen at $-80^{\circ} \mathrm{C}$. The samples were thawed, cleared of cellular debris by low speed centrifugation and titrated for infectivity and hemagglutinating activities.

The results are shown in Fig. 2. The first detectable increase in infectious virus was noted at $4-5$ hours after infection. The logarithmic increase phase was found to occur approximately 5-10 hours after inoculation. Hemagglutinating activity appeared to parallel the logarithmic rise in virus titer and both exhibited a plateau at approximately 
14-16 hours after infection. These results are similar in nature to those presented by Sugiura and Kilbourne (1965), but differ somewhat in that the appearance of virus and the peak of virus production occurred earlier.

\section{Rate of Incorporation of ${ }^{3} \mathrm{H}$-Uridine into Nuclear and Cytoplasmic Fractions}

The temporal sequence of the development of influenza induced incorporation of ${ }^{3} \mathrm{H}$-uridine into acid-insoluble RNA was followed by observing the rate of uptake of label into both nuclear and cytoplasmic fractions

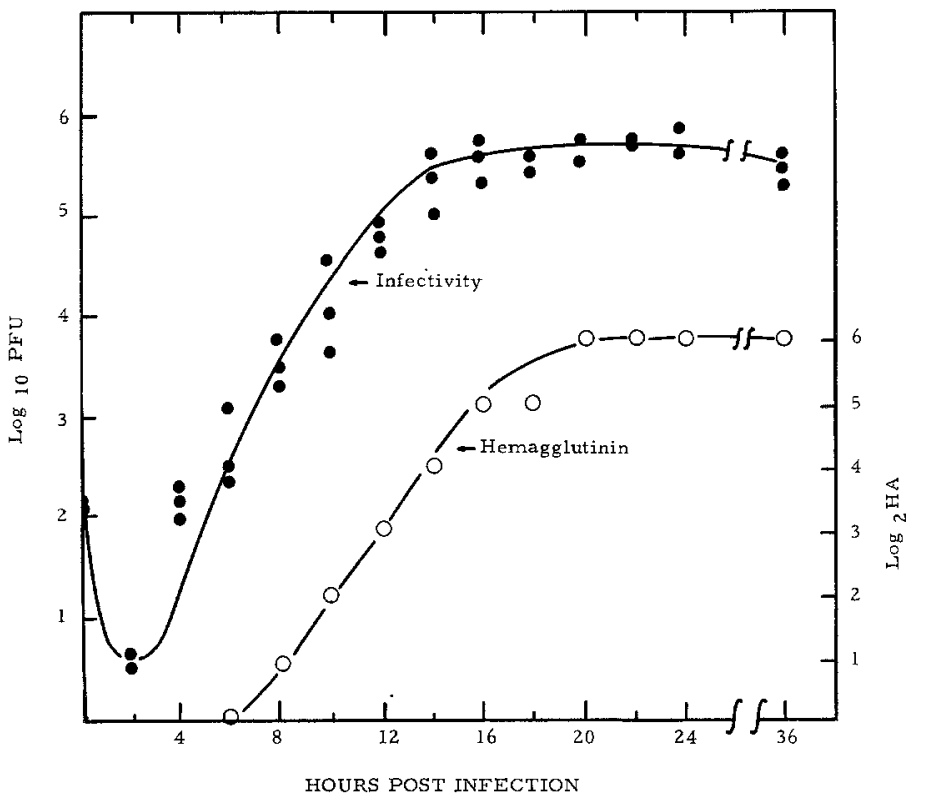

Fig. 2. Growth curve for influenza A/NWS in clone 1-5c-4 of Chang's conjunctival cell.

from infected cells. Although host cell DNA-dependent RNA synthesis may obscure the incorporation of radioactive precursors into virusinduced RNA this difficulty may be overcome by the use of low concentrations of actinomycin D (GranofF and Kingsbury, 1964). When $0.01 \mu \mathrm{g} / \mathrm{ml}$ of actinomycin was used in the maintenance medium of $1-5 \mathrm{c}-4$ cells the rate of incorporation of ${ }^{3} \mathrm{H}$-uridine was reduced by $30-35 \%$. This concentration of actinomycin $\mathrm{D}$ did not significantly affect the yield of progeny virus.

The rate of ${ }^{3} \mathrm{H}$-uridine incorporated into acid insoluble $\mathrm{RNA}$ in influenza A-NWS infected 1-5c-4 cells is shown in Figs. 3a and b. A peak in the rate of incorporation of label into nuclear RNA occurs approxi- 


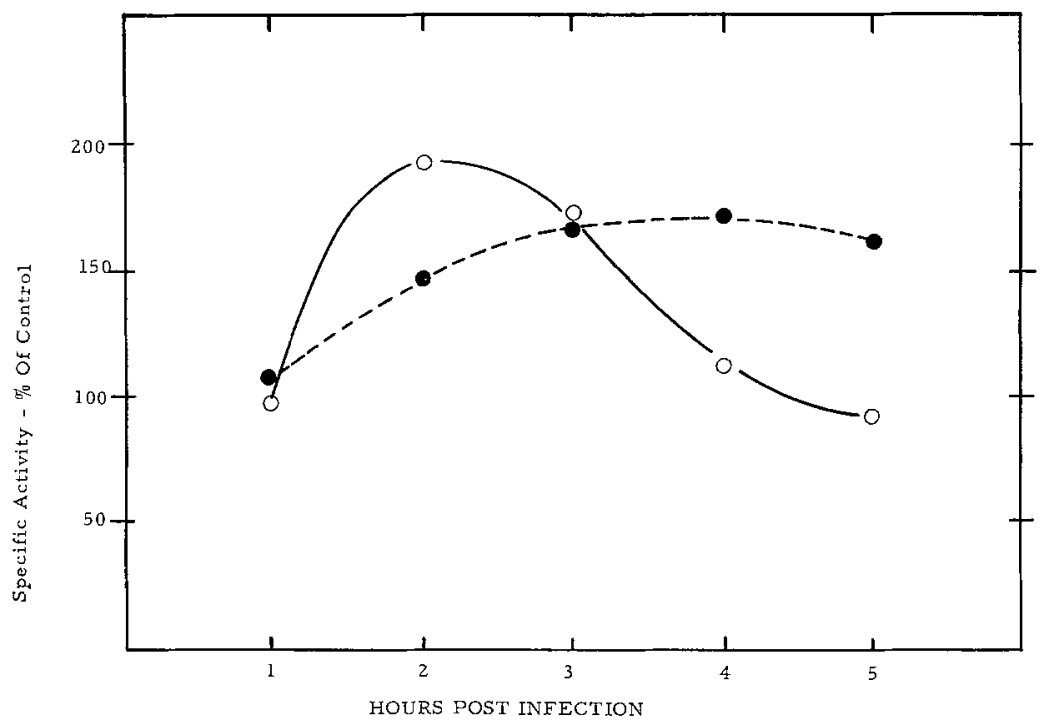

Fig. 3a. Rate of ${ }^{3} \mathrm{H}$-uridine incorporation into influenza virus induced acid-insoluble RNA in 1-5e-4 cells. Samples taken at hourly intervals.

$0-{ }^{3} \mathrm{H}$-Uxidine in nuclear fractions $\quad-{ }^{3} \mathrm{H}$-Uridine in cytoplasmic fractions

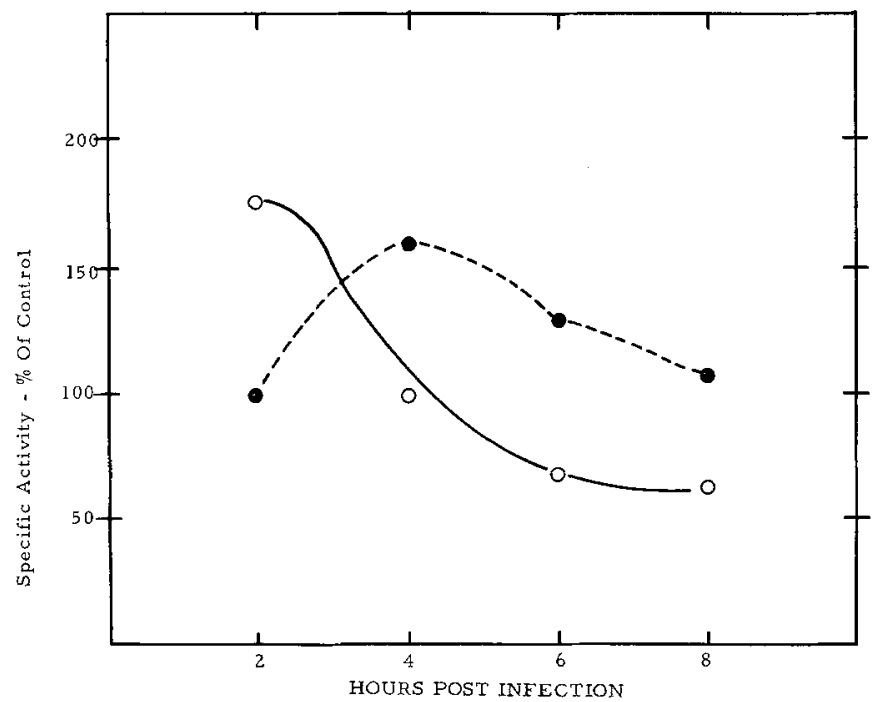

Fig. 3 b. Rate of ${ }^{3} \mathbf{H}$-uridine incorporation into influenza virus induced acid-insoluble RNA in 1-5c-4 cells. Samples taken at 2 hour intervals.

${ }^{3} \mathrm{H}$-Uridine in nuclear fractions

- ${ }^{3}$ H-Uridine in cytoplasmic fractions

mately 2.2 hours after infection. This peak may represent the formation of a pool of replicating viral RNA at this time. The rate decreases rather sharply after 3 hours and then tapers off to a value of about $60 \%$ of 
the control after 8 hours. Observations on changes in the oligonucleotide pattern of nuclear RNA from chick embryo fibroblasts infected with fowl plague virus gave a similar result for the first 3 hours of infection (Scholtisser and RotT, $1961 \mathrm{~b}$ ). Investigations into the presence of labelled acid precipitable RNA in the cytoplasmic fractions showed that a maximum of labelled material in these fractions occurred from 3 to 5 hours after infection. The amount then declined, but was significantly above the control value at 8 hours after infection. This 3 to 5 hour peak corresponds to the first release of infectious progeny virus 4 to 5 hours post infection.

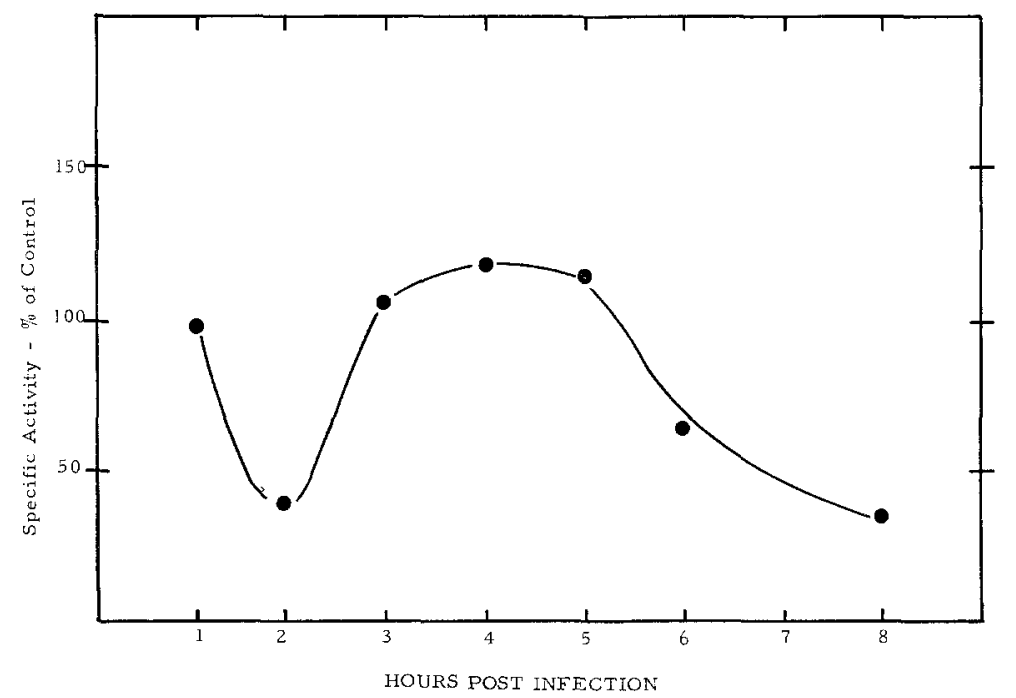

Fig. 4. Rate of ${ }^{3} \mathrm{H}$-thymidine incorporation into acid-insoluble DNA in influenza virus infected 1-5c-4 cells.

Rate of Incorporation of ${ }^{3} \mathrm{H}$-Thymidine into Nuclei of Influenza A-NWS Infected Cells

There has been considerable controversy as to the precise role, if any, of the host cell genome in the development of influenza virus. It was decided to observe the effects of influenza virus upon the rate of ${ }^{3} \mathrm{H}$ thymidine uptake in the nuclei of infected cells. Infected and control cells were pulsed with ${ }^{3} \mathrm{H}$-thymidine 1 hour prior to removal for nuclear extraction and analysis. The results are shown in Fig. 4. There was a profund depression in the rate of incorporation of label during the interval $1-2$ hours after infection. The significance of this depression is not known at this time. The rate of incorporation then increases and is slightly above the control value 3 to 5 hours after infection and then rapidly declines to a value of about $35 \%$ of the control at 8 hours after infection. 
A similar pattern of ${ }^{3} \mathrm{H}$-thymidine incorporation was found in SV5 infected primary monkey kidney cells. However, the initial depression was not as extensive (HoLmes and ChoprL, 1966).

\section{Discussion}

The adaptation of a non-ionic detergent method of cell fractionation to virus infected cells (FISHER et al., 1966) has permitted, in essence, a dissection of the development of influenza-induced RNA in a continuous line of mammalian cells.

The early rise in the rate of ${ }^{3} \mathrm{H}$-uridine incorporation in the nuclear fractions into acid-insoluble RNA suggests that the replication of viral RNA begins soon after the initiation of infection. The peak of labelled RNA seen 2 hours after infection suggests that a pool of replicating virusinduced RNA occurs by this time in the infectious cycle. Observations made on other systems infected with influenza virus i.e., the shift in oligonucleotide pattern from host to viral type RNA in fowl plague infected chick embryo fibroblast nuclei (ScHoLtISSEK and RoTT, $1961 \mathrm{~b}$ ) and the demonstration of the replicative form of influenza virus 0.5 to 1 hour after WSN infection of chick embryo fibroblasts (PoNs, 1967 b) correlate well with our findings.

The presence of a significant amount of labelled acid-insoluble RNA in the cytoplasmic fractions as early as $\mathbf{1 . 5}$ hours after infection may indicate that this RNA is responsible for initiating synthesis of functional viral proteins, such as the neuraminidase or hemagglutinin.

The significance of the profound inhibition of the rate of ${ }^{3} \mathrm{H}$-thymidine uptake by the nuclear fractions from infected cells is still not understood. This depression may result from a physiological alteration of the cells due to the manipulations or perhaps be due to a specific viral function. The relatively rapid return of ${ }^{3} \mathrm{H}$-thymidine uptake to levels above the controls, however, is not construed to be the formation of a new species of DNA coded for by the virus. The evidence for this interpretation is now rather conclusive (RotT, SABER, and Scholtrssex, 1965; Nayak and Rasmussen, 1966; Bell and MaAssab, 1968), but host cell genome function cannot be ruled out as a necessary condition (BoRLAND and MAHY, 1968). The decline in ${ }^{3} \mathrm{H}$-thymidine incorporation after 5 hours of infection may reflect the effects of a generalized cellular derangement due to the infectious process.

Investigations are continuing into the nature of the RNA produced in the nuclei early in the infectious process and its transport to the cytoplasm.

\section{Summary}

A non-ionic detergent method of cell fractionation was used to follow the time course of tritiated uridine incorporation into influenza A-NWS virus-induced RNA in a continuous mammalian cell line. The maximum 
incorporation of tritiated uridine into acid-insoluble RNA of nuclear fractions occurred at 2 to 2.5 hours post infection. A maximum of labelled acid-insoluble RNA of the cytoplasmic fractions was found at 3 to 4 hours post infection which coincided with active synthesis of infectious virus. The effect of influenza A-NWS infection on the rate of tritiated thymidine incorporation into acid-insoluble DNA was found to be an initial depression 1 to 2 hours post infection followed by recovery to near normal values, then a gradual decline until at 8 hours post infection it was approximately $60 \%$ of that shown by the control cell cultures.

\section{References}

1. BeLL, W. C., and H. F. MaAssab: Action of hydroxyurea on multiplication of influenza virus in mammalian cells, Nature (Lond.) 217, 646-647 (1968).

2. Borland, R., and B. W. J. MaHY: Deoxyribonucleic acid-dependent ribonucleic acid polymerase activity in cells infected with influenza virus, J. Virol. 2, 33-39 (1968).

3. Breitenfeld, P. M., and W. Schäfer: The formation of fowl plaque virus antigens in infected cells, as studied with fluorescent antibodies, Virology 4, 328-345 (1957).

4. Burton, K.: A study of the conditions and mechanisms of the diphenylamine reaction for the colorimetric estimation of deoxyribonucleic acid, Biochem. J. 62, 315-323 (1956).

5. Butler, F. E.: Determination of tritium in water and urine, Ann. Chem. 33, 409 (1961).

6. Dische, Z.: "Color Reactions of Nucleic Acid Components", in: The Nucleic Acids (E. Chargafm and J. N. Davinson, eds.), New York: Academic Press 1, 285-305 (1955).

7. Duesberg, P. H., and W. S. Robinson: On the structure and replication of influenza virus, J. molec. Biol. 25, 383-405 (1967).

8. Fazekas de St. Groth, S., and D. M. GrahaM: The production of incomplete virus particles among influenza strains: Experiments in eggs, Brit. J. exp. Path. 35, 60-74 (1954).

9. Fazekas De St. Groth, S., and D. M. Graham: The production of incomplete virus particles among influenza strains: Chemical induction of the von Magnus phenomenon, Brit. J. exp. Path. 36, 205-213 (1955).

10. Fisher, H. W., and H. Harris: The isolation of nucleic acid from animal cells in culture, Proc. roy. Soc. B. 156, 521-523 (1962).

11. Fishre, H. W., and H. HARRIS: Isolation of nucleic acid from animal cell suspensions, Nature (Lond.) 196, 910 (1962).

12. Fisher, H. W., H. Matsumiya, and M. Azuma: Application of cell fractionation techniques in the study of cells infected with polyoma virus and Newcastle disease virus, J. Bact. 91, 1645-1651 (1966).

13. Granoff, A., and D. W. Kingsbury: Effect of Actinomycin D on the replication of Newcastle disease and influenza viruses, in "Cellular Biology of Myxovirus Infections", CIBA Found. Symp. pp. 96-115. Boston: Little Brown \& Co., 1964.

14. HANKS, J. H., and R. E. WALLACE: Relation of oxygen and temperature in preservation of tissues by refrigeration, Proc. Soc. exp. Biol. (N.Y.) $71,196-200$ (1949). 
15. Holmes, K. V., and P. W. Choppin: On the role of the response of the cell membrane in determining virus virulence. Contrasting effects of the parainfluenza virus SV5 in two cell types. J. exp. Med. 124, 501-520 (1966).

16. Munro, H. N., and A. Fteck: The determination of nucleic acids, in "Methods of Biochemical Analysis", D. GLICK (ed.), pp. 113-176. New York: Interscience Publishers, 1966.

17. NAYAK, D. P., and A.F. RASMUSSEN : Influence of mitomycin C on the replication of influenza viruses, Virology 30, 673-683 (1966).

18. NAYAK, D. P., and M. A. BALUDA: Isolation and characterization of nucleic acid of influenza virus. J. Virol. 1, 1217-1223 (1967).

19. NAYAK, D. P., and M. A. BALUDA: Ribonucleic acid synthesis in cells infected with influenza virus. J. Virol. 2, 99-109 (1968 a).

20. NAYAK, D. P., and M. A. BALUDA: An intermediate in the replication of influenza virus RNA, Proc. nat. Acad. Sci. (Wash.) 59, 184-191 (1968 b).

21. Pons, M. W.: Studies on influenza virus ribonucleic acid, Virology 31, $523-531$ (1967a).

22. Pons, M. W.: Effect of actinomycin D on the replication of influenza virus and influenza virus RNA, Virology 33, 150-154 (1967b).

23. Rott, R., S. Saber, and C. Scholtissek: Effect on myxovirus of mitomycin $\mathrm{C}$, actinomycin $\mathrm{D}$, and pretreatment of the host cell with ultraviolet light, Nature (Lond.) 205, 1187-1190 (1965).

24. Schmidt, G., and S. J. Thannhauser: Method for determination of desoxyribonucleic acid, ribonucleic acid, and phosphoproteins in animal tissues, J. biol. Chem. 161, 83-89 (1945).

25. Scholtrssek, C., und R. Rотт: Zusammenhänge zwischen der Synthese von Ribonucleinsäure und Protein bei der Vermehrung eines Virus der Influenza-Gruppe (Virus der klassischen Geflügelpest), Z. Naturforsch. $16 \mathrm{~b}, 663-673$ (1961 a).

26. Scholmissek, C., und R. RotT: Untersuchungen über die Vermehrung des Virus der klassischen Geflügelpest. Die Synthese der virusspezifischen Ribonucleinsäure (RNA) in infizierten Gewebekulturen embryonaler Hühnerzellen. Z. Naturforsch. 16b, 109-115 (1961 b).

27. Scholtissek, C., R. Rott, P. Hausen, H. Hausen, and W. Schäfer: Comparative studies of RNA and protein synthesis with a myxovirus and a small polyhedral virus, Cold Spr. Harb. Symp. quant. Biol. 27, $245-257(1962)$.

28. StUart-HarRis, C. H.: A neurotropic strain of human influenza virus, Lancet 1, $497-499$ (1939).

29. Sugiura, A., and E. D. Kilbourne: Genetie studies on influenza viruses. II. Plaque formation by influenza viruses in a clone of a variant human heteroploid cell line, Virology 26, 478-488 (1965).

30. WONG, S. C., and E. D. KILBOURNE: Changing viral susceptibility of a human cell line in continuous cultivation. I. Production of infective virus in a variant of the Chang conjunctival cell following infection with swine or N-WS influenza virus. J. exp. Med. 113, 95-110 (1961).

Authors' address: Dr. W. C. BELL, Virus Laboratory, Department of Epidemiology, School of Public Health, University of Michigan, Ann Arbor, MI 48104, U.S.A. 